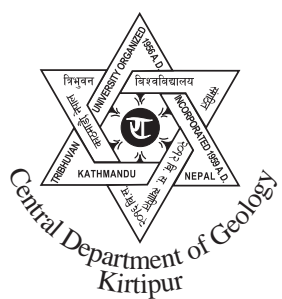

\title{
Carbonaceous schists of the Main Central Thrust zone as a source of graphite: a case study from the Kali Gandaki valley, west Nepal
}

\author{
*Lalu Prasad Paudel \\ Central Department of Geology, Tribhuvan University, Kathmandu, Nepal
}

\begin{abstract}
Petrological study and X-ray diffraction analysis were carried out to identify the content and quality of graphitic material in the carbonaceous schist from the Main Central Thrust zone in the Kali Gandaki valley, west Nepal. The study shows that the carbonaceous schists contain more than 15-30\% graphite. They contain both amorphous and flake graphite with variable grain size. As graphite is being mined commercially in rocks containing even $<5 \%$ graphite worldwide, carbonaceous rocks of the Main Central Thrust zone can be a potential sources of commercial graphite in Nepal.
\end{abstract}

\section{INTRODUCTION}

The Lesser Himalaya and the Main Central Thrust zone (MCT zone) of Nepal comprises a number of carbonaceous metasedimentary rocks (black slates and phyllites and schists) (Stöcklin 1980; Sakai 1985; Paudel and Arita 2000) interbanded with pelitic and psammitic metasediments. They have been metamorphosed to greenschist facies (about $30^{\circ}-35^{\circ} \mathrm{C}$ ) in the Lesser Himalaya. The metamorphic temperature reaches much higher $\left(>50^{\circ} \mathrm{C}\right)$ near the Main Central Thrust where rocks are in the lower amphibolite facies (Paudel and Arita 2000; Kaneko 1997). Study of carbonaceous rocks in the Lesser Himalaya of Pokhara-Syangja area by Paudel (2010) shows that carbonaceous rocks contain significant amount of graphite.

Carbon recrystallizes to graphite at $200^{\circ} \mathrm{C}$ in sedimentary rocks (Lindgreen 1933), and the metamorphic temperature in the Lesser Himalaya and the MCT zone is enough for the transformation of carbon to graphite. Therefore, the carbonaceous rocks of the Lesser Himalaya and the MCT zone have high potential for the graphite formation. Paudel (2010) confirmed that the carbonaceous rocks of the Pokhara-

\footnotetext{
*Corresponding author:

E-mail address: lalupaude167@yahoo.com
}

Syangja area contain amorphous to crystalline graphite and can be commercially mined. Most of the world's graphite deposits are also formed by regional or contact metamorphism of carbonaceous sedimentary rocks (Lindgreen 1933; Lamey 1966; and Bateman and Jenson 1990).

In the present study, petrographic and X-ray diffraction analysis were carried out in the samples from the Tatopani-Dana area in the Kali Gandaki valley (Fig. 1). The study shows that the carbonaceous rocks contain considerable amount of graphite which can be extracted for commercial purposes.

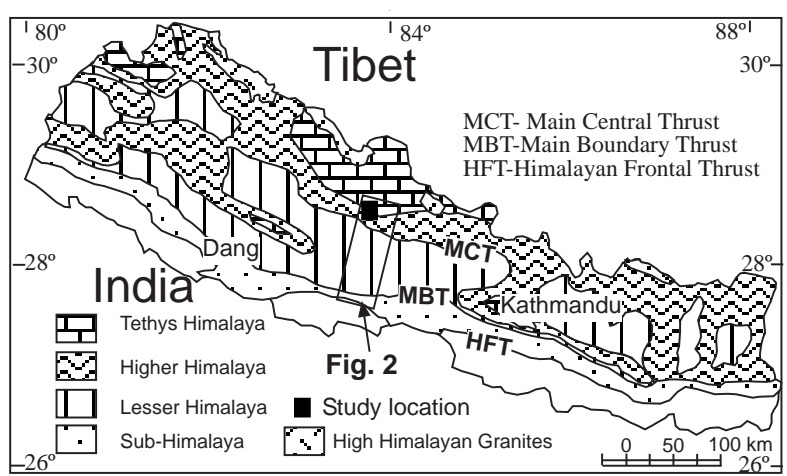

Fig. 1 Geological Map of Nepal showing the location of the study area (modified from Paudel and Arita, 2000). 


\section{GEOLOGICAL SETTING AND OCCURRENCE OF CARBONACEOUS ROCKS}

Study area lies in northernmost part of the Lesser Himalaya near the Main Central Thrust in the Kali Gandaki valley (Fig. 2). The Lesser Himalayan rocks in the area belong to the Nawakot Complex of Stöcklin (1980). In the study area, the road section south of Tatopani comprises Kunchha Formation and Fagfog Quartzite (with amphibolite). The Fagfog Quartzite is overlain by highly sheared and metamorphosed rocks of the MCT zone along the Lower MCT (Fig. 3).
The Lowermost unit of the MCT zone in the area is pelitic schist, quartzite and marble. It is followed upsection by carbonaceous schists of about $2 \mathrm{~km}$ thickness. The carbonaceous schists are highly sheared and internally folded. It is lead black in colour on fresh outcrops as well as in hand specimens (Fig. 4a and 4b). It has soapy lustre and gives black streak. The carbonaceous schist may be the metamorphosed equivalent of the Benighat Slate.

The schist shows rusty weathering on some surfaces due to alteration of pyrite. A few bands of calc-phyllite are observed in this unit. The uppermost unit of the MCT zone is the granitic augen gneiss, most probably equivalent to the Ulleri Augen geniss.

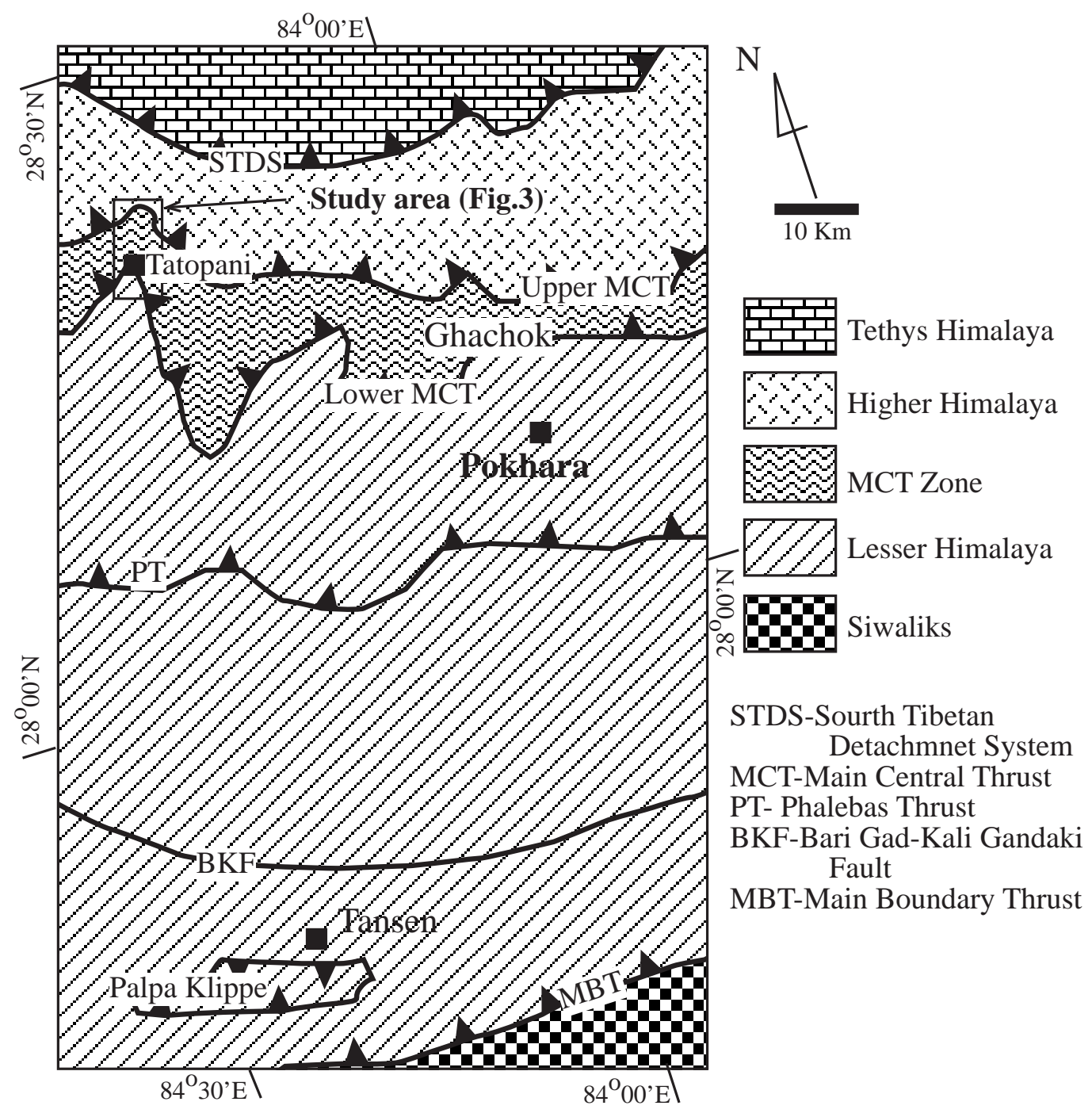

Fig. 2 Schematic tectonic map of the Pokhara-Butwal area showing the location of the study area. (Map modified from Paudel and Arita, 2000). 
Fig. 3 Geological route map along the Kali Gandaki valley between Tatopani and Dana showing the black schists.

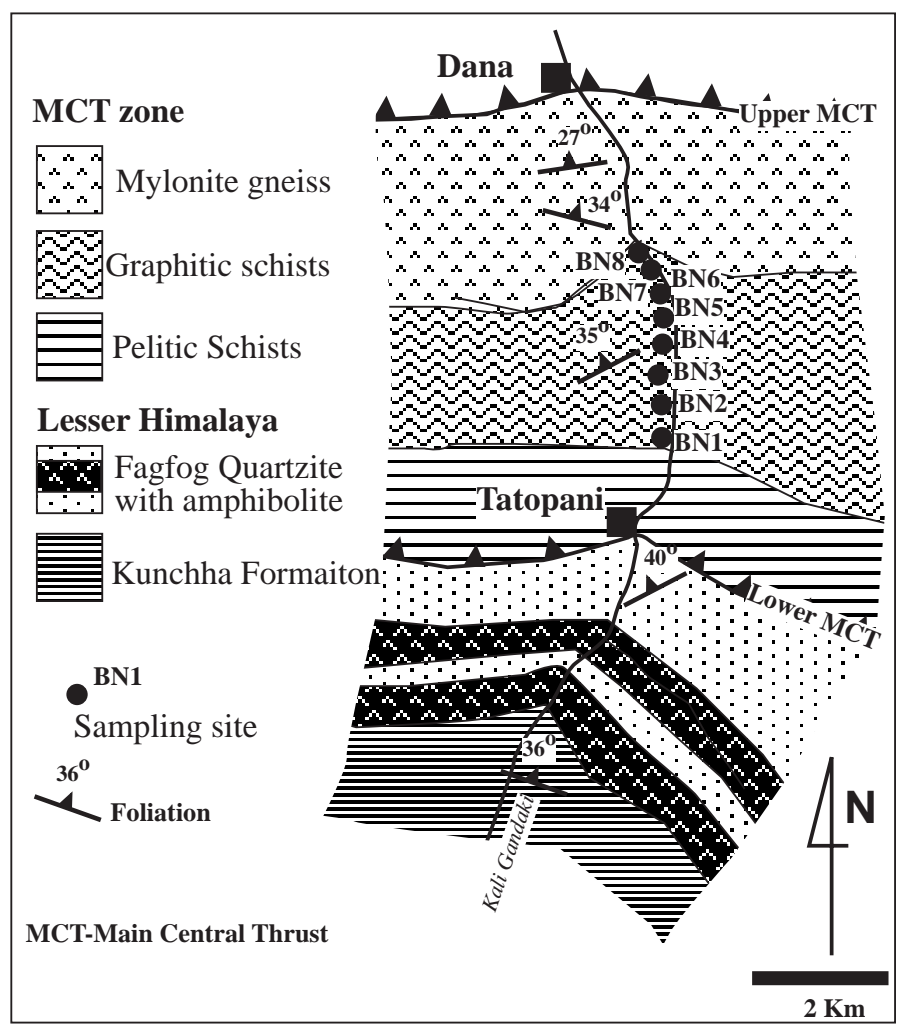

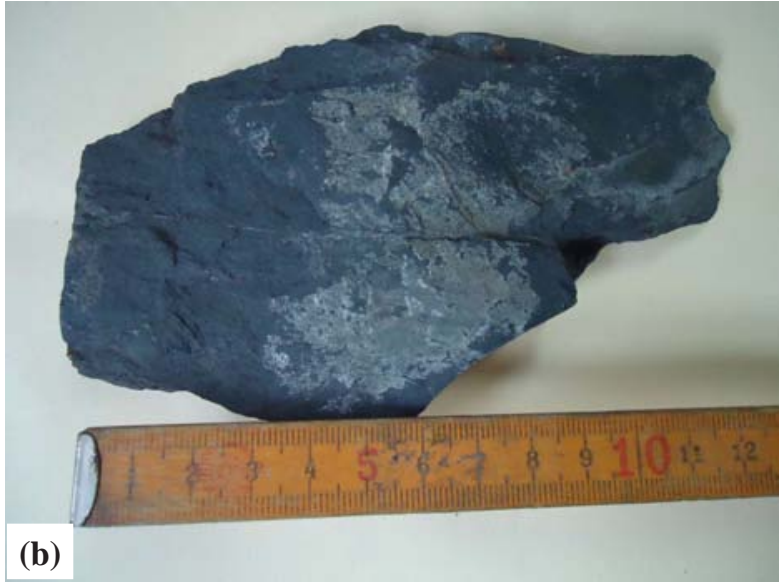

(b)

Fig. 4 (a) Photograph of carbonaceous schist outcrop north of Tatopani, and (b) Photograph of the carbonaceous schist in hand specimen.

\section{STUDY METHOD}

Altogether 8 samples were regularly taken along the road section from Tatopani to Dana. Samples were selectively taken from the layers which has possibility of high carbon content. Graphite analysis was carried out according to standard procedure given in Mitchell (1993). Thin-sections were prepared from all the samples and were studied under the petrological microscope mainly to know the mineralogy, grain size and texture of the rock.
Carbonaceous material was extracted from the samples (Fig. 5a) following the methods described in Griffin (1967). The bulk samples were crushed to pass a 60-mesh sieve, then boiled four minutes in $20 \%$ hydrochloric acid and washed twice with distilled water. The washed sample was again boiled five minutes in 50\% hydrofluoric acid then washed four times with distilled water dried at less than $50^{\circ} \mathrm{C}$.

The separated carbonaceous fractions were packed in a grooved sample holder (Fig. 5b) and studied by D8-Advance X-ray Diffractometer at the Central 


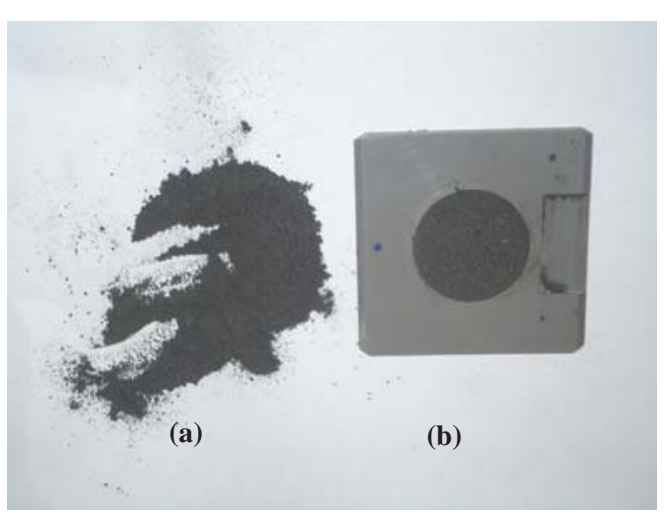

Fig. 5 (a) Carbonaceous material separated from the schist. (b) Carbonaceous material filled in grooved sample holder of Xray diffractometer.

Department of Geology, Tribhuvan University. The Diffractometer was controlled as $\mathrm{Cu}-\mathrm{K} \alpha, 40 \mathrm{KV}$ tube voltage, $40 \mathrm{~mA}$ tube current, Ni-filter, $1 \mathrm{~mm}$ divergence slit, $0.2 \mathrm{~mm}$ scatter slit and $1 \mathrm{~mm}$ receiving slit. The Diffractometer was run between $25^{\circ}$ and $28^{\circ}$. A well-crystallized graphite gives sharp (002) peak between $26-26.5^{\circ}(\mathrm{d}=3.43-3.36 \AA)$ (French 1964). The diffractograms were analysed and interpreted using the DiffracPlus softwares.

The quality of graphite was evaluated on the basis of grain size, crystallinity, and percentage of carbonaceous material.

\section{RESULTS}

\section{Results of petrographic study}

The percentage of the minerals in the samples was determined by point count method. The summary of mineralogical content is given in the Table 1 .

Under the microscope, all the samples contain dominantly graphite (15-30\%), quartz (25-40\%) and muscovite $(15-30 \%)$. Biotite is present in minor amount (3-15\%). Sample no BN1 and BN5 contain up to $10 \%$ garnet. The feldspar (albite) content ranges from 5 to $10 \%$. The rocks are highly sheared and foliated. The foliation is defined by the parallel arrangements of graphitic materials, muscovite and elongated quartz. The graphitic material is flaky, and fine- to medium-grained (0.1 to $1 \mathrm{~mm}$ ) (Fig. 6). Quartz show ribbon structure. Biotite is sometimes porphyroblastic. Biotite shows pale yellow to brown pleochroism. The biotite fishes contain asymmetric inclusions. Albitic plagioclase occurs as sheared porphyroclasts as well as recrystallized matrix. The albite porphyroclasts have subhedral to anhedral shape and are up to $0.5 \mathrm{~mm}$ in diameter.

\section{Results of X-ray diffraction analysis}

Carbonaceous materials in metasedimentary rocks recrystallize to form graphite structure with increasing diagenesis and metamorphism and reaches to the fully ordered graphite. This recrystallization is called graphitization and can be examined by the X-ray powder Diffractometer.

X-ray diffraction analysis in the present study shows that they contain well-crystallized graphite. Very sharp and prominent peaks were obtained at about $26.5^{\circ} \mathrm{C} 2 \theta$ positions in all the samples. The prominent peaks belong to graphite (Fig. 7). The graphite peaks in some samples (BN3 and BN4) samples from the lower part of the unit area relatively wide and intensity count is low ( $<300$ count per second) (Fig. 7a). However, the graphite peaks form the upper part (BN7) are relatively narrow and the intensity count is high (>350 count per second) (Fig. $7 \mathrm{~b})$. As the width and intensity of the peaks is controlled by the degree of graphitization, it can be suggested that the quality and content of graphite increases upwards towards the MCT.

Table 1: Summary of mineralogy in the studied samples.

\begin{tabular}{lcccccccc}
\hline \multirow{2}{*}{ Sample No. } & \multicolumn{7}{c}{ Mineral content in $\%$} \\
\cline { 2 - 9 } & Graphite & Quartz & Feldspar & Muscovite & Chlorite & Calcite & Biotite & Garnet \\
\hline BN1 & 20 & 35 & 5 & 15 & $\mathrm{x}$ & $\mathrm{x}$ & 15 & 10 \\
BN2 & 25 & 30 & 5 & 25 & $\mathrm{x}$ & $\mathrm{x}$ & 3 & 2 \\
BN3 & 20 & 40 & 10 & 20 & $\mathrm{x}$ & $\mathrm{x}$ & 10 & $\mathrm{x}$ \\
BN4 & 25 & 30 & 10 & 20 & $\mathrm{x}$ & 5 & 10 & $\mathrm{x}$ \\
BN5 & 15 & 30 & $\mathrm{x}$ & 20 & $\mathrm{x}$ & $\mathrm{x}$ & 10 & 10 \\
BN6 & 15 & 30 & 10 & 25 & 15 & $\mathrm{x}$ & 5 & $\mathrm{x}$ \\
BN7 & 25 & 25 & 10 & 30 & 10 & $\mathrm{x}$ & $\mathrm{x}$ & $\mathrm{x}$ \\
BN8 & 15 & 35 & 10 & 25 & 15 & $\mathrm{x}$ & $\mathrm{x}$ & $\mathrm{x}$ \\
\hline
\end{tabular}



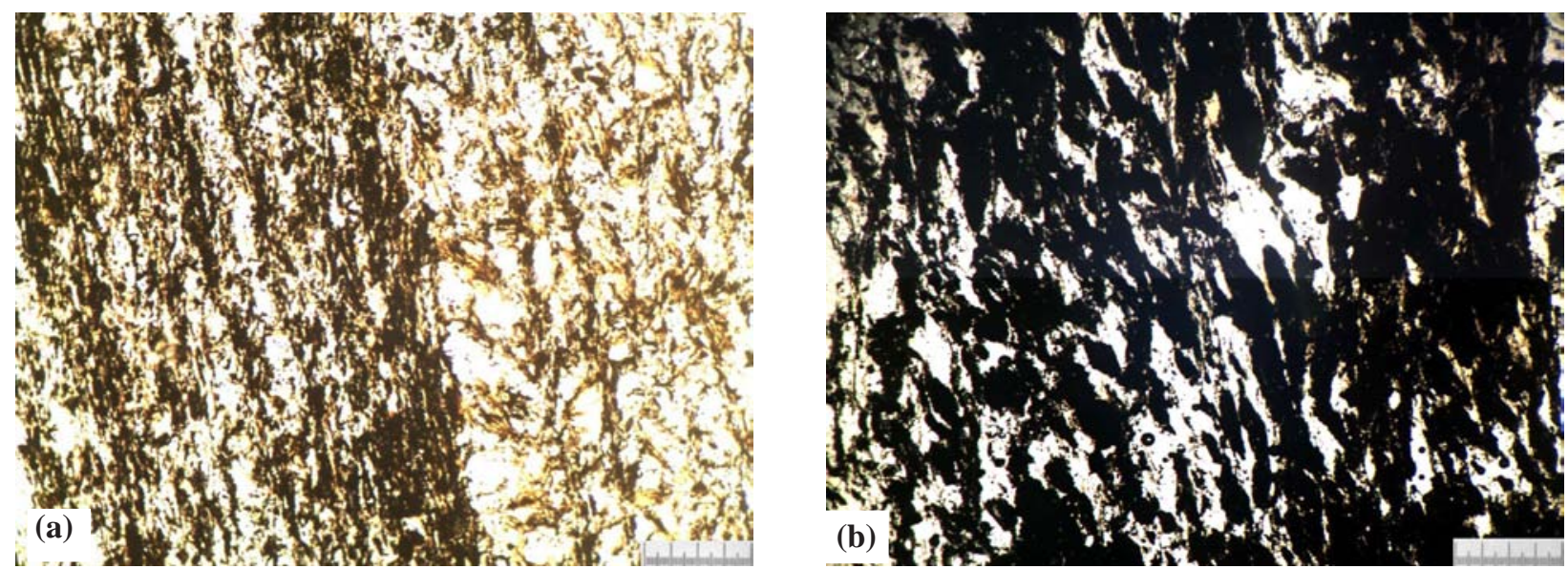

Fig. 6 Representative photomicrograph of carbonaceous schists: (a) Under plain polarized light and (b) Under crossed nicol. (Scale one small division $=0.01 \mathrm{~mm}$ ).
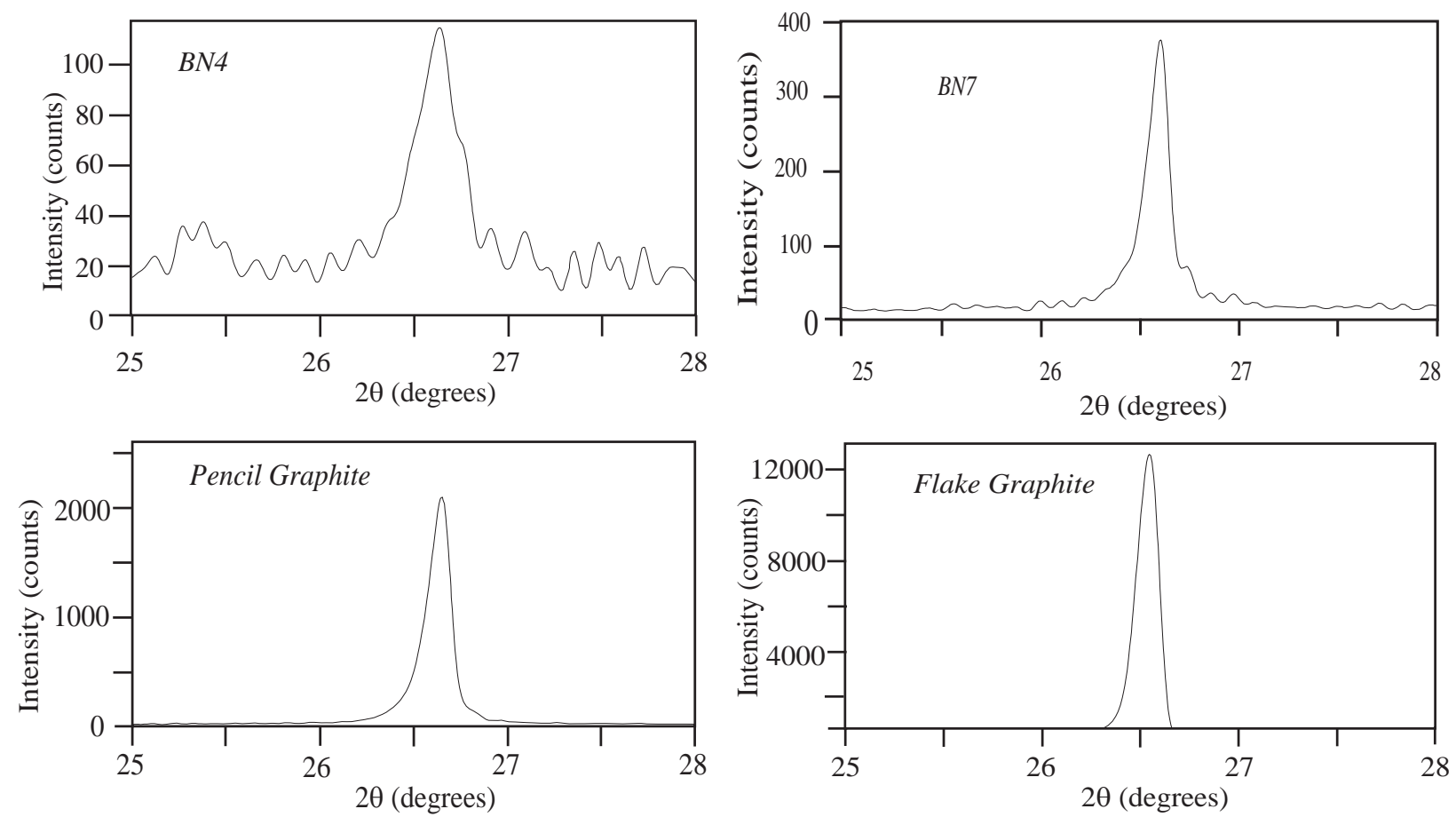

Fig.7 (a) and (b) Representative X-ray diffractogram of graphite in the carbonaceous schists. X-ray diffractograms of graphite in lead pencil (c) and flake graphite (d) are given for comparison.

\section{DISCUSSIONS}

Commercial graphite is classified as amorphous and flake (Flogg and Boyle 1987). Amorphous graphite is cryptocrystalline and grain size is $<70 \mu \mathrm{m}$. Flake graphite is phaneritic and grain size is $>70 \mu \mathrm{m}$. The carbonaceous schists in the present study area contain crystalline graphite as shown by well-defined peaks in X-ray diffractograms. However, the grain size of graphite varies from place to place. The graphite in the carbonaceous schist from the lower part of the unit is fine- to very fine-grained (cryptocrystalline, $<70 \mu \mathrm{m}$ ) and appears as randomly disseminated mass or scaly material under the petrological microscope. This graphite can be classified as "amorphous" graphite. Graphite in the samples from the upper part of the unit is usually coarse- to very-coarse-grained ( $>70 \mu \mathrm{m})$ and can be classified as graphite.

A review of graphite mines worldwide indicates that deposits containing graphite as low as 5\% are 
Table 2: Comparison of graphite in the present area with other famous graphite mines in the world. Informaiton about the graphite in Ghachok and Walling is from Paudel (2010). Information about the other mines is from Bateman and Jenson (1990).

\begin{tabular}{|l|l|l|l|}
\hline Place & Host rock & Graphite type & Percentage \\
\hline 1. Germany (Passau, Bavaria) & Micaceous schists and gneiss & Amorphous to finely crystalline & $10-30 \%$ \\
\hline 2. South Korea (Kyonsang-Pukto) & Phyllite, Schits and marbles & Amorphous to flaky & $3-4 \%$ \\
\hline 3. Ceylon (Sabaragmuwa Province) & Gneiss, granites & Lump in veins & $>90 \%$ \\
\hline 4. Madagascar (Tamatave) & Schist and gneiss & Flakes & $4-11 \%$ \\
\hline 5. Mexico (Sierra de Moradillas) & Metamorphosed coal layers & Amorphous & $85-95 \%$ \\
\hline 6. United States (Alabama) & Mica schist & Flakes & $1-5 \%$ \\
\hline 7. Ghachok, Kaski & Black schist & Crystalline flakes & $20-30 \%$ \\
\hline 8. Walling, Syangja & Black slate & Amorphous & $15-25 \%$ \\
\hline 9. Present area & Black schist & Amorphous and crystalline & $15-30 \%$ \\
\hline
\end{tabular}

being mined commercially (Table 2). In the present area, graphite content is more than $15 \%$ in all the samples. Therefore, carbonaceous rocks of the MCT zone in Nepal may be potential sources of graphite.

\section{CONCLUSIONS}

The MCT zone in the Tatopani-FDana area of the Kali Gandaki valley comprises a very thick unit of carbonaceous schists. Petrographic study and X-ray diffraction analysis of samples from those rocks show that they contain 15 to $30 \%$ graphite. Although the grain size of graphite is variable, it is well crystalline and is appropriate for industrial purpose. As graphite is being mined commercially in rocks containing even $<5 \%$ graphite worldwide, carbonaceous rocks of the MCT zone in Nepal can be regarded as a potential sources of commercial graphite.

\section{ACKNOWLEDGEMENTS}

I am grateful to the Central Department of Geology for providing laboratory facilities. I thank L. N. Rimal for fruitful comments on the paper.

\section{REFERENCES}

Bateman, A.M., and Jenson, M.L., 1990. Economic mineral deposits (third edition). John Wiley and Sons, New York, 593 p.

Flogg, C.T. and Boyle, E.H., 1987. Flake and highcrystalline graphite availability and market economy countries. US Bureau of Mines Information Circular 9122.

French, B.M., 1964. Graphitization of organic material in a progressively metamorphosed Precambrian Iron
Formation. Science, v. 146, pp. 917-918. http://dx.doi.org/10.1126/science.146.3646.917 PMid:17777057

Griffin, G.M., 1967. X-ray diffraction techniques applicable to studies of diagenesis and low rank metamorphism in humic sediments. Journal of Petrology, v. 37, no. 4, pp. 1006-1011.

Kaneko, Y., 1995. Thermal structure in the Annapurna region, central Nepal Himalaya: implication for the inverted metamorphism. Journal of Mineralogy, Petrology and Economic Geology, v. 90, pp. 143154. http://dx.doi.org/10.2465/ganko.90.143

Lamey, C.A., 1966. Metallic and industrial mineral deposits. McGraw-Hill Book Company, London, 567 p.

Lindgreen, W., 1933. Mineral deposits. McGraw-Hill Book Company, London, 930 p.

Mitchell, C.J., 1993. Industrial Minerals Laboratory Manual: Flake Graphite. British Geological Survey Technical Report WG/92/30, Mineralogy and Petrology Series, 35 p.

Paudel, L.P., 2010. Exploration of commercial grade graphite deposit in the Pokhara-Syangja area, west Nepal Lesser Himalaya. Research report submitted to the University Grant Commission, $31 \mathrm{p}$.

Paudel, L.P., Arita, K., 2000. Tectonic and polymetamorphic history of the Lesser Himalaya in central Nepal. Journal of Asian Earth Sciences, v. 18, pp. 561-584. http://dx.doi.org/10.1016/S13679120(99)00069-3

Sakai, H., 1985. Geology of the Kali Gandaki supergroup of the Lesser Himalaya in Nepal. Memoirs of the Faculty of Science, Kyushu University (Japan), Series D, Geology, v. 25, pp. 337-397.

Stöcklin, J., 1980. Geology of Nepal and its regional frame. Journal of Geological Society of London, v. 137, pp. 1-34. 